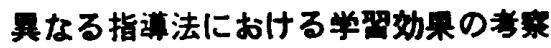

第一轱团体目

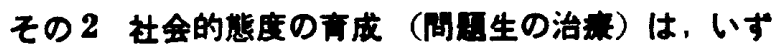
れの方法かより望ましい倾向を示すか. 屡児岛大学 金 子 喜三市 森屋男 ○土屋正幸

\section{I 指道法別の变化}

1. 向上者の此較 そのリで述へたように異なる指導 法の中、B 案では態度の育成については特に Guidance を個人並に集団に行つた，その結果 組別向上者の割合 は，第!表にみると拈り，男子において，B案で指導を 行い, 然も生徒数が最も少いは組が最る高い值を示し，

第।表向上者の割合と向题生の变化

\begin{tabular}{|c|c|c|c|c|c|c|c|c|}
\hline \multirow{2}{*}{\multicolumn{3}{|c|}{ 分 }} & \multirow{2}{*}{\begin{tabular}{|c} 
男 \\
A 项的上 \\
\end{tabular}} & \multirow{2}{*}{\begin{tabular}{c|} 
子 \\
BI项目伿上
\end{tabular}} & \multirow{2}{*}{\multicolumn{2}{|c|}{ 12 }} & \multirow{2}{*}{$\frac{\text { 女 }}{\text { AIN䀢向上 }}$} & \multirow{2}{*}{ 手 } \\
\hline & & & & & & & & \\
\hline \multirow{3}{*}{$\begin{array}{l}\text { 向 } \\
\text { 点 } \\
\text { 者 } \\
\text { 烈 } \\
\end{array}$} & w) & $A$ & $40.22 \%$ & $53.19 \%$ & 11 & $A^{2} B^{\prime}$ & $53.36 \%$ & $48.89 \%$ \\
\hline & 3 & $B$ & 40.40 & 58.33 & 12 & B & 42.75 & 63.04 \\
\hline & 13 & $B$ & 72.00 & 76.00 & & $B$ & 75.00 & 85.00 \\
\hline \multirow{3}{*}{$\begin{array}{l}\text { 间 } \\
\text { 题 } \\
\text { 生 } \\
\text { 变 } \\
\text { 化 }\end{array}$} & $w$ & $A$ & $\frac{1}{6}$ & $-\frac{3}{6}$ & 12 & $A^{2} B^{\prime}$ & $\frac{2}{6}$ & $\frac{4}{6}$ \\
\hline & 万 & $B$ & $\frac{4}{6}$ & $\frac{6}{6}$ & 12 & B & $\frac{2}{6}$ & $\frac{6}{6}$ \\
\hline & 12 & B & $\frac{3}{4}$ & $\frac{3}{4}$ & & B & $\frac{3}{3}$ & $\frac{3}{3}$ \\
\hline
\end{tabular}

次に同しく B 案を用いたろ組の順となつている，女子 そついては，Negative の項目の向上に㧊けるは組とに 祖の顒位が異るが他は男子と同様の傾向を示していると 云うことができよう。

2. 問題止の炃化 Guess-who Test の結果, Negative の面伛いいて, 多くの指名を受けた子供を問題生と し，B 案では凡的る機会に個人別 Guidance を行つた 絬果，第1婊の下闌化示すとおり，その欠陥とされる Negative の面において男子万組忹6 名中全買，組 4 名中 3 名，女子に組，一組共全員の向上がみられるのに 対し, $\mathrm{A}$ 案乃至 $\mathrm{A}^{2} \mathrm{~B}^{1}$ 案を用いたい組およびは組にお。 いては，前者程の向上者数がられない。

以上の結果から態度育成上 Guidance の効果が顕著 であることが察知されるがそれと其にクループの助け合 い活動化負了処も亦大きいことがクルーブ日誌を通じて

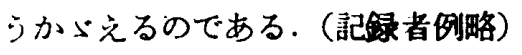

な打問題生の中，向上を示さなかつた生徒の性格特性 をみると共通して思考力に乏しく，消極的行動頃向にあ
ることが認めウれるるこのことは、生活においいて䋖えず

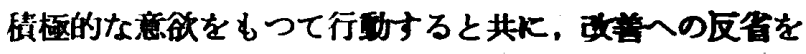
行5能方が如何に必要であるから首肯できよ5.

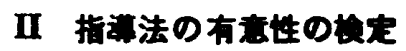

Guess-who Test の結果, Positive およひ Negative の両面から，全く同異と思われる者の対を作つて指前法 間の有意性の検定を実施した結果は，第 2 表炕示すと括 りである. すなわち男子で Positive の項目において5\%

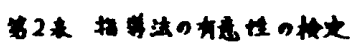

\begin{tabular}{|c|c|c|c|c|c|c|}
\hline \multicolumn{2}{|c|}{$\mathrm{N}^{\mathrm{A}} \mathrm{n}$} & \multicolumn{2}{|c|}{ 多 } & & \multicolumn{2}{|c|}{ * 子 } \\
\hline 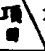 & & $t$. & $\mathbf{P}$ & & t. & $\mathbf{P}$ \\
\hline \multirow{2}{*}{$\begin{array}{l}\hat{A} \\
\text { 皇 }\end{array}$} & い村了 & 2.39 & 0.05 & $11+12$ & 0.25 & \\
\hline & $3 甘 13$ & 3.23 & 0.01 & $12+8$ & 2.65 & 0.05 \\
\hline \multirow{2}{*}{$\begin{array}{c}\text { B } \\
\text { 项 } \\
\mathbf{B}\end{array}$} & vit3 & 2.46 & 0.05 & WAnk & 0.11 & \\
\hline & 3却12 & 1.93 & 0.10 & loA & 0.58 & \\
\hline
\end{tabular}

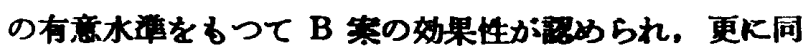
じB 案で指導を行つたろ組対は組では，生唗数の少い は組が $1 \%$ の有意水港で買的な高まりを示している．女 子については， A2B1 案と B 策との間には有意性は㑇 められないが，B 案を用いたに縕とへ組の間には 5\%の 有意水淮をるつて男子同楼生徒数の少い組の高主りが琵 められる.

Negative の㮩目については，男子において B 秉を 用いろ組の方に 5\%の有意水酒で妙果が梕められるが。 B 案を同しくく用いたろ租対は組の間の 有意水语は 10\% と云う高い值を示している．女子については，有意性が 哚められなかつた。

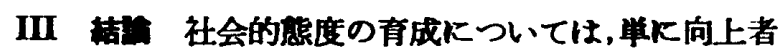
の棇数からだけでなく，その界的な高まりの点から6

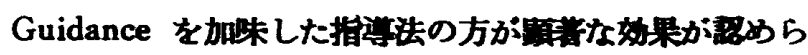

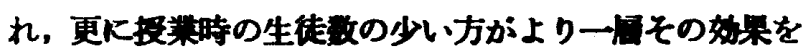
高めていると云らことができよう.

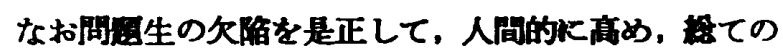
者の学習活栜や日常の生活を明るく染しくするといら立

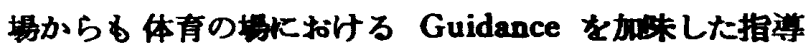
法が今後重要視されて然るべきであると云えよ5．更に 研究題目その 1, その 3 の学習㚳果を併せ考えると $\mathbf{A}$

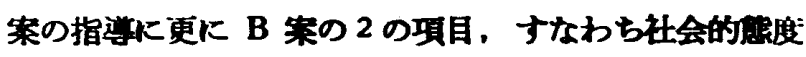
の問屏生に対し特別の Guidnce を范すとすればハレ

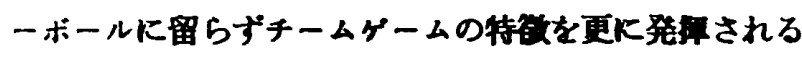
のではないかと推宜される. 